\title{
PUBLIC BUILDINGS OF ARCHITECT MILAN ZLOKOVIĆ - AFFIRMATION OF MODERN ARCHITECTURE IN SERBIA
}

\section{A B S S T R A C}

This article is conceived as a contribution to the study and understanding of modern architecture in Serbia and Yugoslavia in the period between the two world wars. The subject of this study is the architectural practice of architect Milan Zloković, one of the most important actors of architectural modernism in the forthcoming period. The focus of research is Zloković work on the design and implementation of public buildings with emphasis on the four objects: Hotel "Žiča" in Mataruška Banja (1931-1932), Building Children's University Clinic in Belgrade (1933-1936/1940), Building Elementary School in Jagodina (1937-1940) and FIAT Automobile Building Service in Belgrade (1939-1940). This phase of Milan Zloković practise is distinguished by authentic character of the author in the study of geometric forms, proportional analysis, applied materials and construction, all in new forms of organization of space in the spirit of modern architecture postulates. 


\section{INTRODUCTION}

This paper, originating from the author's master's thesis pursues the architectural design within the context of research into the history and theory of the twentieth century architecture and also engages in the analysis of modern architecture principle on the constructed public buildings in the third and the fourth decade of the twentieth century in Serbia. More precisely, the subject of the paper is the critical analysis of the modern architecture application in architectural and urban discourse in the cities of Serbia of that time, being the buildings of the architect Milan Zloković, realized at that time in diverse urbanspatial and public-cultural context. Within the master's thesis, the following realized buildings have particularly been analyzed from the critical point of view: the "Žiča" hotel in Mataruška banja (spa) (1931-1932), the building of the University Clinic for Children in Belgrade (1933-1936/1940), the building of the elementary school in Jagodina (1937-1940) and the "FIAT" building in Belgrade (1939-1940). The above mentioned public buildings, specific for their architectural expression, were realized according to the principle of modern architecture and present the specific features of their application in the Serbian cities. They also present the characteristics of Zlokovic's architectural expression, his particular modernism and contemporariness with the European trends in architecture of that period. The above mentioned designs, derived from the design and architectural typology of the public buildings (catering, health, educational and business ones), originated within the context of the initiative of the public and private investors regarding the introduction of the modern movement in the Serbian architectural and public discourse, which made the modern movement certain and competitive with the actual academic architectural expression of that time.

However, during the twenties of the twentieth century there came to the socio-political conditions and key, crucial events in the contemporary cultural discourse which would open the way towards the modern art and avant-garde, out which the emergence of zenithism, the presence of the Czechoslovakian and Russian artistic stage, the first CIAM (Congrès International d'Architecture Moderne) in La Sarase (Switzerland) and forming of the "GAMP" (GAMM) (The Group of Architects of Modern Movement) in 1929, are singled out. It can be concluded that both Serbia and Yugoslavia in the process of creation of the new contemporary cultural identity, notwithstanding the economic and social problems, had and in one part made use of the possibility of modernism implementation in its social-cultural habitat. The power of the idea and contemporariness will classify Serbian modernism in the overall European image of contemporary art and architecture. 
Milan Zloković arrived in Belgrade in 1919 after having first started his studies in Graz. He graduated in 1921 and the same year he left for perfecting his skills at L' École Superrieure des Arts et Mètiers and L' École des Houtes Etudes in Paris.

According to the statements of Zoran Manević: "there is no information that in Paris Zlokovic moved in the circles of the modernists, nor that he was willing to accept their ideas absolutely; that, among others, is demonstrated also by his first designs prepared upon his arrival in Serbia, which were fully academically conceived."

Upon his return to Belgrade in 1923, Zloković became employed with the Engineering School, at the Department of Architecture, as per the recommendation of the professor Dragutin Đorđević, and thus his academic career begun as well. A conclusion can be drawn that Zloković's works until 1927 - when the family house of the Zlokovićs was realized in Kotež Neimar, which is deemed the first designing deviation towards modernism - varied from the romantic academism to secession personified in the local tradition, however, also to the four-pitch roofs of the Rights" " Prairie houses". In order to get a full picture on the architectural practice, a tabular survey was formed, in which the designs, competition entries and realizations of Milan Zloković from 1921 until 1941 were processed. In December, 1928, Milan Zloković and Branislav Kojić participated at the Yugoslav competition for the new building of the Maritime museum in Split. This work of Zloković's, which was without any placement (the buying award was won by Kojić), was designed in the refined modernistic spirit and for that reason we will concentrate on it. The design of the Maritime museum incorporates in itself also a trait of wider character, the symbolism, which later on we encountered also in Brašovan's design for the Pavilion in Barcelona dating 1929. With Zloković the angular motifs with balconies quite surely make an association to the ship bow, which completely corresponds to the context of the use of the building. In Brašovan the association is of a more indirect character, like a form arousing the need for movement, making progress. ${ }^{2}$

The building of the Maritime Museum in the section and the plans affirm decisively the adherence to the modernistic principles of architectural forming. In the section, the diverse heights of the space in the ground-floor and at floor levels correspond to their diverse uses (the principle of use of the raumplan in the public building). Window openings were not unified, their dimensions corresponded to the interior spaces functions, whereas the same windows were 
joined by horizontal strips, and that was one of the ways of achieving a close link of the front and the side tract. From this Zloković's design, and throughout the entire period of modernism, the angular steel flag mast became a frequent decorative motive in architecture.

"The social transformation, the sudden development of industry and prewar particularly more reasonable perception had a favorable influence upon the development of the latest architecture. There were already people who knew how to perceive a building as the assembly/ set of various plan- linked functions, requiring thereby constructive truth and purposeful application and treatment of material. The ingenious study of the real requirements of the program affected also the basic problem solution. The architect has finally felt the importance, which purpose the building was constructed for." ${ }^{3}$

This idea from Zloković's text "The Old and the New Understanding", published in 1931 in Ljubljana magazine Arhitektura, clearly suggested his constructive and modernistic determination for the pure, clear and functional architectural program. In the coming years Zloković used this standpoint also in the housing architecture opus (house/villa) and in the public buildings opus, which the further research of Zloković's modernistic discourse will focus on, and which does not tackle the case study. In this paper, besides the competition entry for the Maritime Museum in Split, the three implemented buildings are singled out.

THE “ŽIČA” HOTEL IN MATARUŠKA BANJA (1931-1932)

“...The sketch of the Hotel in Mataruška Banja, with its simplicity, smooth surfaces, harmony of proportions and the opening rhythm represented the pattern aspired to by the contemporary architecture today."4

Đurđe Bošković, the review of the First Yugoslav exhibition of Modern Architecture, Vreme, February 28, 1931.

In the design for the "Žiča" hotel in Mataruška Banja, Milan Zloković did not show any traces of any historicism, mannerism, decorativeness. The dates of the preliminary sketches and the design are uncertain for now. In his autobiography, a veritable document, Zloković, according to the statements of Zoran Manević, placed hotel design in the period between 1929 and 1931. However, it is not likely that Zloković would miss exhibiting his first biggest hotel "in the American spirit", as the contemporaries used to say", at the Salon of architecture in 1929, at the Exhibition of Forms in 1939, or at the Exhibition 
of the works of the GAMM members in Prague, in 1930. The design drawings and the sketch for the "Žiča" hotel in Mataruška banja, were exhibited by Zloković only at the First Yugoslav exhibition, in February, 1931, and the chances are that they originated few months earlier, i.e. at the end of 1930. The construction started in the fall of 1931, and it was completed in May, 1932.

"In banja (spa) environment, at the place where there was a row of small houses, which were already destroyed last year, a modern arranged park was erected. At the place of the old restaurant, which was destroyed in the fall, the modern "Žiča" hotel was constructed. The hotel covers the area of almost one thousand square meters. The construction of this hotel, without interior design, cost approximately two million dinars. The hotel has thirty rooms of the most modern comfort. The restaurant was provided for over three hundred people, and the terrace can seat two hundred guests. The hotel was constructed according to all the contemporary architecture rules. The design architect is Mr. Milan Zloković, the assistant professor at the Belgrade University. The hotel owner is Mr. Dezider Hovan." ${ }^{5}$

"It suffices to say that it would also do credit to the foreign countries..." "Žiča" hotel was the symbol of Banja and provided it with its main characteristic. It consisted of the ground-floor level and the first floor level with thirty rooms. Above the first floor level there was the terrace with several hundreds seats. The terrace was richly decorated with multi-colored Chinese lanterns and flowers. The terrace had a wonderful view of Kraljevo and the surrounding area, and was used for performances and summer cinema. During summer the music played on the terrace, and the grilled delicacies were served. In winter it was foreseen that terrace would be used as a skating ring, the cabins were built, however, this plan was ruined due to the beginning of the World War Two." "

In order to acquire greater number of beds and enlarge the capacity of the restaurant, following the War, in 1951, the second floor was additionally built and the restaurant was expanded. With the additional building the hotel has lost mush of its aesthetic appearance and remained without its main attraction - the terrace.

According to the testimony of the academician Đorđe Zloković, the professor of architecture, the son of Milan Zloković, in the conversation conducted by this paper's author, the concept for the construction of the modern building struck the hotel owner, i.e. the private client, after he had become familiar with Zloković's modern expression, particularly with the architecture of the 
family house in Kotež Neimar. His decision could have been influenced also by the private acquaintance with Zloković. According to the researches of Ljiljana Blagojević, "Žiča" hotel in Mataruška banja was the first in series of uncompromising buildings. Located in the center of the small spa town, with the anti-contextual and anti-historical white architecture, it stands out from the environment of the dormant provincial town.

"Like the ship, this building with flat roof terrace as the deck, cinema screen ropes as the rigging, projection cabin as the navigation bridge and the smooth stem/hull with strictly arranged cabin portholes, dismisses the town and leaves it behind. In the times yet to come the local population has got a firm grip of the departing hotel, reconstructing it drastically in the sixties, thus running it aground for ever into the lethargy of its own commonplaceness."

The hotel is situated in the arranged spa park, completed in 1933, within the circle of the existing spa pavilions constructed with the eclectic and secession details of the façade plastics and characteristic slanting roofs. At first the hotel modern architecture - deprived of any traditional elements and urban small town context - with its purity and whiteness in that context had a sensational appearance. With the flat roof, cubic form and large restaurant in the building ground-floor level with the canopy/awning - it gave the impressions of the Mediterranean hotels and ships which adorned the ports and the coast of the Mediterranean. The building volumetry is made of the corpus with a large restaurant in the roofed porch of the twice as high floor height and service rooms in the ground floor and a narrower accommodation part with thirty rooms, fifteen on each side of the communication. The inventiveness is represented by the functional rooms and sanitary blocks interior solutions, "the ships cabins".

The window opening rhythm is precisely made proportional in Zloković's manner and its disposition - the elegant, simple and functional - clearly emphasizes the façade play of the full and the empty. The absolute modernism of the hotel is manifested by Zloković by means of a flat roof (deck) which with its entire surface is used multi-purposely - as an open cinema, natural solarium for sun-bathing and rest or the restaurant in the open. In support of this is also the fact that such principle of the fifth façade has repeated one of the five Le Corbusier's points of architecture and fully affirmed functionalism and modern aesthetics of the thirties of the twentieth century. The impression is more attractive more so as the communications to the roof terrace are meandered underneath the projection cabin in the sprit of Mediterranean and Boka stone hairpin-bends, which Zloković recognized in the stone architecture 
of the native Boka and the Adriatic, but also in the external communication of. Le Corbusier's Maison Citrohan. Here the paradigm of tradition and modernism can easily be found and which Zloković sums up and composes in his geometrical and functional expression. Steel metal fences with the outdoor lighting are installed along the roof terrace, and with the erected frame for the projection screen (the sail), besides the screen function, Zloković solves also the static system against the wind effect.

Functionality and reduced cubic form with façade opening modulation and pure white surfaces defined the "Žiča" hotel as the first public Zloković's work realized in the postulate of modernism and is rightfully defined as the "residential machine". Comparative analogy is found in the building of DOMKOMUNA by Moysey Ginzburg dating 1926, where the principle of using the roof for the house user stay is apostrophized by pergola structure (the paradigm of the ship command bridge), façade treatment and functional organization of the accommodation units.

The authenticity of "Žiča' hotel was degraded in a vulgar way by expansion of the capacity and rough additional construction in the sixties of the last century. The building lost then its original volumetry and the roof terrace, and the hall and garden restaurant volume were particularly devastated. Neglected noticeably, the hotel - in which presently in fully inadequate conditions live the families displaced from Kosovo and Metohija - presents the opponent to he concepts of modern house affirmation in Serbia of that time and its synthesis with the heritage and tradition.
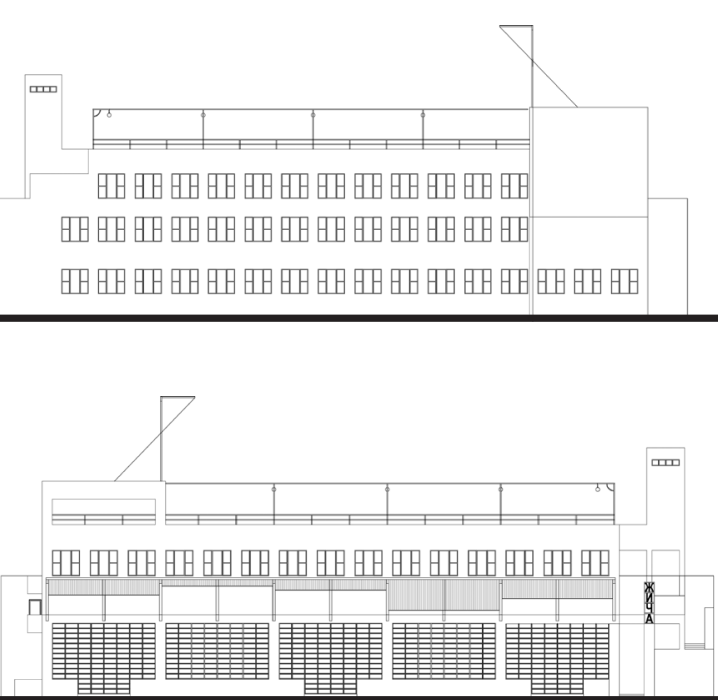

Figure 1 The "Žiča” Hotel in Mataruška banja, facades 
THE BUILDING OF THE UNIVERSITY CLINIC FOR CHILDREN IN BELGRADE (1933-1936-1940)

The most important Zloković's work, the design for the building of the University Clinic for children in Belgrade, was created in 1933, at the same time and in the same manner like Brašovan's work - the building of the State Printing House. According to Zoran Manjević, these two buildings are at the same time, without any dilemma, the most significant examples of the Serbian modern architecture at all. This statements can be deemed universal only if this works are also added to the works of other Serbian modernists, regardless of where they worked, in the first place the work of Nikola Dobrović - as the unrivaled advocate of modernism, particularly in the Dubrovnik period / but also the other modernists. If this statement is focused on the territory of Serbia, we can take it as a narrower geographical determinant.

Dating the process of designing and construction is not an irrelevant coincidence, since it shows that both Zloković and Brašovan arrived to their most powerful concepts just in the middle of the period of mature modernism in 1933 and realized them in the period of the late modernism (1936-1940).

Had the design of the Children's Clinic actually originate in 1931, Zloković surely would not miss exhibiting it at the Second Yugoslav exhibition, held in February, 1933. On this occasion, however, he exhibited less import design of the Stock Exchange, in two variants. Manjević's presumption on the manner and strategy of exhibiting Zloković's works at the exhibitions can here be considered as subjective. The first trace on the acute need to build the Children's Clinic appeared in the daily papers - in the newspaper Pravda dated May 1, 1933, in the text of M.A. Nikolić " Humanity Bids that Belgrade should get a Modern Children Hospital." $"$

The next newspaper's article, by the anonymous author, published on October, 11, 1935 in the newspaper Vreme under the heading "Belgrade to Acquire a New Modern University Clinic for Children" presented the history of this establishment and the grave conditions in the barracks at Guberevac, where the institution was housed. Further on in the text one can read: "Due to all of this, the Head of the Children's Clinic, professor Dr. Matija Ambrožić, as soon as he took the office few years before, begun to be engaged in the issue of construction of a large and modern Children's Clinic. For that purpose he traveled across Switzerland, Germany and the Netherlands, studying the children's clinics in those countries which had been constructed in the most modern manner. Following that he returned to Serbia where with the support of 
many friends and competent persons, he managed to create a good atmosphere for the start of the construction, and really three years before the municipality granted the parcel of land for erecting that grand and useful institution in the vicinity of old Zvezdara..."10

In 1940, Ivan Zdravković published the critical text on the design of the University Clinic for Children in the daily paper Pravda. The greatest part of the attention was paid to the functionalistic values in Zloković's work: "Each opening for illuminating a certain room was positioned where it should have been and of the size dictated by the very size of the room to be illuminated. Which explains why these openings were not of the same sizes and were asymmetrically arranged, but that did not prevent the entire appearance to yet give a harmonious and pleasant impression. There is a certain rhythm felt between the openings and the surfaces, and also between the unequal heights and diverse roof finishes." 11

While designing the University clinic for children Zloković chose as paradigm the just completed and widely published Paimio sanatorium for the Tuberculars in Finland, the work of Alvar Alto, designed in 1929, and realized in 1933. The building of Sanatorium in Paimio was at that time visually artistic and functionally the most successful medical building, implemented as per the principles of architectural functionalism. With its indented wings, in which the total of 290 sick-beds was accommodated, this sanatorium free of any rigidity was placed harmoniously into its environment. The windows of the sick-rooms faced the south-south-east. This building, as the successful implementation of the purist understanding of architecture of the thirties, represented the most significant work of contemporary architecture in the north of Europe of that time. The boldness in view of the selected structural system renowned Alto as the author. The building was well executed and plastically sculpted, so that it makes the spatial-time experience of the visual art impressions possible. Even despite certain plastic units being static, each wall has its own role. ${ }^{12}$

From the stationary part of Alto's building in Paimio Zloković took over the sequences of terraces in front of the sick-rooms, which in both cases made the extension of the accommodation units in direction of the nature and fresh air and served as kind of solarium. Another essential characteristic was introduced in the design of the Children's clinic by Zloković - the opening on facades were dimensioned in harmony with the room surface size and use and which were illuminated through those openings, whereby he met the generally accepted hygienic requirement for insolation of the accommodation rooms and the 
existence of terraces for the patients to stay in the sun. Both in the case of Alto's sanatorium, but, also in the other medical buildings of that time constructed in modernistic and functionalistic postulates, terraces were designed with the same purpose. It is interesting that during the execution Zloković stressed deliberately the similarity of his design to Alto's sanatorium subsequently introducing above the attic, facing Pasterova street, a visible framework structure, the detail which did not exist in the published axonometric sketches of the building at the beginning of its construction. ${ }^{13}$

However, besides the analogy to Alto's sanatorium and architecture of ship decks by decomposing the primary building form, the architectonics of the Polyclinic and "Žiča" hotel can be defined in the spirit of Maljevič's architectons. In the early twenties Maljevič made the first architectons, the indication of the new step in suprematism coming closer to architecture. Those were real three-dimension compositions, the rough models of the original architectural compositions in which the horizontal and vertical parallelepipeds of various proportions and sizes become merged and woven at right angles. Actually, Malevich, only with the three-dimensional suprematism and architectons started behaving as an architect, presenting his concept on the future residential buildings which he named the planites. ${ }^{14}$

Malevich's shaped aesthetic experiments with geometric figures, solids and color being the means for achieving rhythmic spatial organization had a powerful influence on the development of the style methods and forms in contemporary architecture and design. Composition of form of Zloković's Children polyclinic represents a horizontal architecton, i.e. the planite with its own author's standpoint of composition of the main corpus displaced axis, with genially proportioned façade fabric (carcass).

Zloković's comment in respect to the clinic composition is that the building graded volumetry was the result of the therapeutic departments requirements; however, the character of the building was presented numerically, through modular mass network. He particularly emphasized the combination of continuous modular system in the longitudinal direction and the intermittent space which stretched between the bearing brick walls in the diagonal direction.

At facades the effects of the dominating modular appearance emerge as the result of the interaction of the smooth wall surfaces and standardized, series window and door openings. The basic window types consist of two elements, the wall surface cut out and the order with slightly pronounced stone frames: 
the window and fanlight (oberlicht - a roof window, the derivative of the ship portholes covered with transparent material serving for light letting through). Such window units were repeated in all hospital rooms, with the openings placed around horizontal axes which should have provided the required minimum air circulation and illumination, whereas in the bottom parts there were standard double windows with wooden joints. The balcony doors were directly derived from the basic type, with the use of the standard windows which stretch as long as the floor level, or with the windows without transversal beams, where adequate. Such window unit structure is the consequence of the pragmatic requirements, but their formal articulation requires geometrical analysis. Given that their proportion and modular co-ordination was obviously systematically and consistently defined throughout the building, the issue on positioning and on intriguing dimensions of the two openings and transversal beam between them are the most essential ones.

Starting from the façade wall basic modular unit, marked by the modular network lines in the width and with the two top floor slabs in the height, the rectangle is obtained the relation of measures of which is $1: 2$. Given that the window width is fixed by the brick wall fixed structural dimensions, which wall is between the openings, the height and the position of the two basic figures has to be determined geometrically. Zloković's design work again presents the guideline for understanding the design procedure.

In the first step the height of the façade unit rectangular figure is divided according to the gold section rules in order to define the major determining axis for window units design. Thus the dimension of the forms with transversal beam are determined by designing the dynamic rectangle, namely the rectangle with the side relation being 1 , and generatrix (the length of the
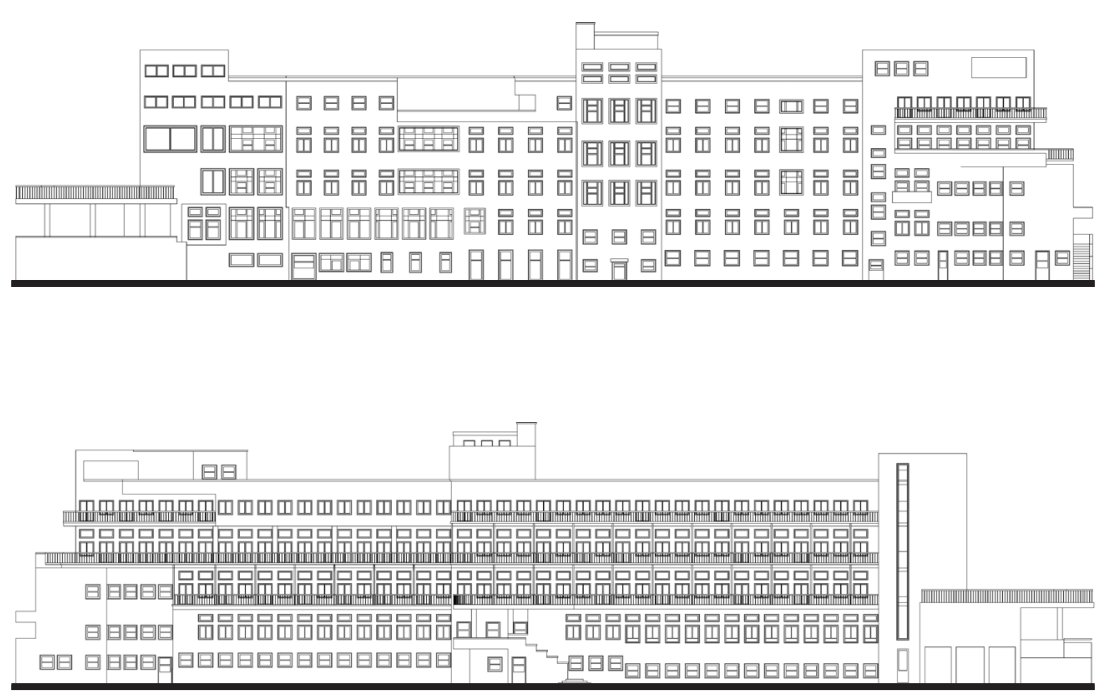

Figure 2 The Building of The University Clinic for Children in Belgrade, facades 
line of the rotating solid on the drawing which, by following the geometric solid model, generates an imaginary length on its external side) divides into the square and another rectangle of the same proportion. In the following step the rectangle is further divided, following the diagram from Zloković's work, in order to demonstrate that one can arrive to all parts of the window unit (which in reality is true) in a geometric way. In the end, when the dimensions are calculated on the basis of the diagram and compared to the actual dimensions on the building, the proportional analysis is confirmed as being that much precise that even the window frame thickness is identical to the calculation from the drawing.

The clinic was conceptualized in 1933 as a modernistic building, constructed during the years preceding the World War Two, thereafter it was badly damaged during the bombing of Belgrade and renovated and completed in the post-war period. Poorly maintained and almost neglected in the years to come, in the end it was deprived of its form by ignorant interventions in the last decade of the twentieth century. The last blow was with the recent erection of the brick wall in the place of the spacious transparent façade of the admittance department in the elevated ground-floor level. Inadequate additional construction and destruction of the primary architectonics of Zloković's buildings was defined in the best manner by Ljiljana Blagojević in her book: "Could this wallingup present anything else but a kind of barbaric violence being the extreme opposition confronting the idealistic position of the emancipatory designs which Zloković offered in his modernism?"15

\section{THE BUILDING OF THE ELEMENTARY SCHOOL IN JAGODINA $(1937-1940)$}

The Building of the Elementary school in Jagodina, the work realized between 1937 and 1949, which for that purpose functioned until 1951, when it was decided that "Svetozar Marković" high school should move into that building, which still exists there nowadays. The building possesses certain similarities with the competition design for the Ethnographic museum in Belgrade dating 1938 , only that in this case the monumentality was appeased by prevalence of the window openings spaces over the wall (solid mass) on side facades and the elements of main façade asymmetric solutions.

Architectural concept of the school in Jagodina can be perceived as a remote reflection of the Italian rationalistic movement of that time. The possible influence upon Zloković's school architecture can be considered to be "the 
canonic work of the Italian rationalistic movement" (as stated by Kenneth Frampton), Casa del Fascio in Como, the work of Giuseppe Terragni (19321936), particularly in the use of modular rectangular openings on the façade. Still, even if this was the source of inspiration, it has to be perceived within the context of Zloković's rigorous selection of constructional references.

In that sense his list of illustrations for the lectures held at the Faculty of Architecture is indicative, where he starts from the sketches of the steam engines, hangars, "Normandy" ship, then switches to the high rises, including Le Corbusier's plan of Buenos Aires, and the pictures of the residential buildings in Milan which were the work of Pietro Lignerie and Giuseppe Terragni, in order to finally arrive to Casa del Fascio in Como.

The school building is located in the central city park, immediately next to the temple of the St. Petar and Pavle and the spacious park cornice with pedestrian paths, and with its front façade corresponds towards the park and the constructed neighboring buildings, namely the church, enclosing the angular motive (barrier) along the promenade axis. With the pure, refined façade, Zloković dissonantly formed the proportional and modular network of the window openings, thus affirming the cadre of the "new" school.

The façade facing the park is symmetrical with six horizontal rows of windows, and functionally, two row each illuminated the classrooms interior, creating the inverse play of the light and the shadow, the full and the empty in the form of the dark window strips on the white and pure Zloković's façade fabric/ carasse on the outside, and darker tones of the walls in the classroom and corridors interior which let the sun light and air to permeate and thus met the requirement for the hygienic stay of the students.

Such inversions were present in many examples of the white modern architecture, and therefore the studies of many masters modernists were based on the analysis of the house facades, illumination and atmosphere in the interior, as well as the concrete, the primary material.

The building corpus is made of two tracts forming the angular set of the Cyrillic letter $\Gamma$, and the space of the school yard with sports terrains formed the school square, enclosing with the building a rectangular urban composition.

Aleksej Brkić, in his book Znakovi u kamenu, presents his belief that Zloković had arrived at the façade solution for the building of the Elementary school in 
Jagodina by his feeling for the free disposition and expression of the image and that such solution is a very good example of geometrical deregulation of the orthogonal axial and geometrical ordinature. That means of regulation, which functionalism had to accept from the succession, as his own measure of purpose, and if he literally adhered to it, would not disturb the organization of the building façade plane, Zloković used to execute the façade from the rigid grid of the strict orthogonal convergence, and thus at the same time established the rhythm of the higher range of order, "for the first time in Serbian modern architecture to find the consonance in the public addressing axes moving and finally, with this deregulation to start a play which plausible disharmony would find itself in contact with the concrete architecture play, and definitely will no longer respect canonic rules if they reverse it to the rhythm of the first instance values." 16

Ljiljana Blagojević notices that Zloković with yet another building of exceptional purity and clarity of geometrical system shifted the boundaries of the Serbian urban provincial environment further. In the design of the Elementary school in Jagodina the starting point and the way towards the abstract aesthetics were to some extent different than in the "Žiča" hotel. In this building his researches focused on the drastic minimalization of the constituent elements. The entire school design rests on the consistent use of the modular network, both in the plan and in the structural system, and also in the execution of the basic form and individual façade elements. With white walls and without any articulation of the secondary areas, the building from the street looks like a block of the halved cube. In articulation of facades Zloković denounced all but the usual window module and its expressiveness being the strict contracts to the massive wall surface. Limiting himself to the exterior, he would plunge into work of constructing the sequences of linked, two-dimensional forms

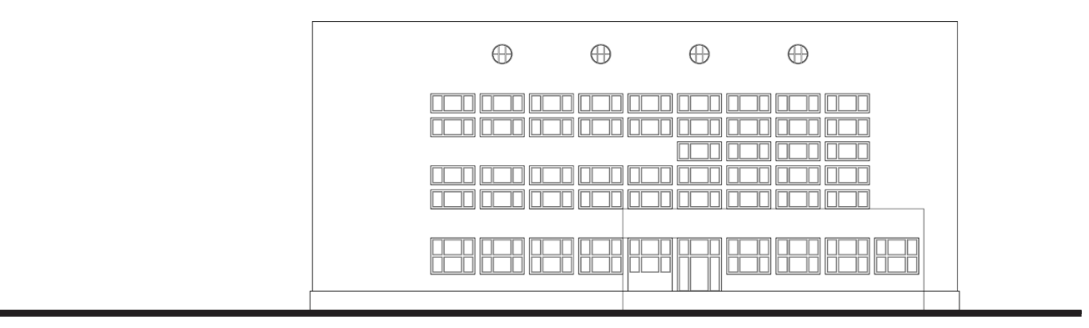

$\oplus \quad \oplus \quad \oplus \quad \oplus$ 
of abstract aesthetics. As soon as he would complete that, he would use the unconnected modular network composed of standard windows of rectangular shape, with the relation of the width to the height being 9:4, and concrete reinforced structure elements which formed the window frames. Thus formed network made it possible for him to fill the inner-space with bricks, for example parapets, with window openings across the entire façade space, and then to place the composition of building appearance at his liberty. Linking the basic rectangular figure to the geometrical structure of the classic 1: B5 rectangle, Zloković harmonized not only diverse types of window and door openings but also the correlation of the elements of the entire building form.

\section{THE “FIAT” BUILDING IN BELGRADE (1939-1940)}

After Children's polyclinic, the "FIAT" building is one of the most significant Zloković's works. It originated at the time of the full influence of the totalitarian ideology, and was intended for the industrial giant of the fascists Italy of that time. On this building there are no traces of monumentalistic tendencies of the late modernism or ideological bases of the rationalistic architecture of the totalitarian regimes.

Even notwithstanding the powerful conceptual pressures, the influences spreading since the World EXPO in Paris in 1937, until March's (March Werner, 1894-1976) design for the Olympic stadium in Belgrade in 1940, Zloković did not use the direct paradigm in designing the "FIAT" building. There was no need for that. He remained autonomous, faithful to his builder's ideal, order, measure and harmony. Even though already at the age of forty three, there was a vast builder's experience behind him. For the "FIAT" building, Zloković like a true master, used the syntax of the Italian rationalism with several skillfully selected literal citations. The analogy of composing and lining the façade with

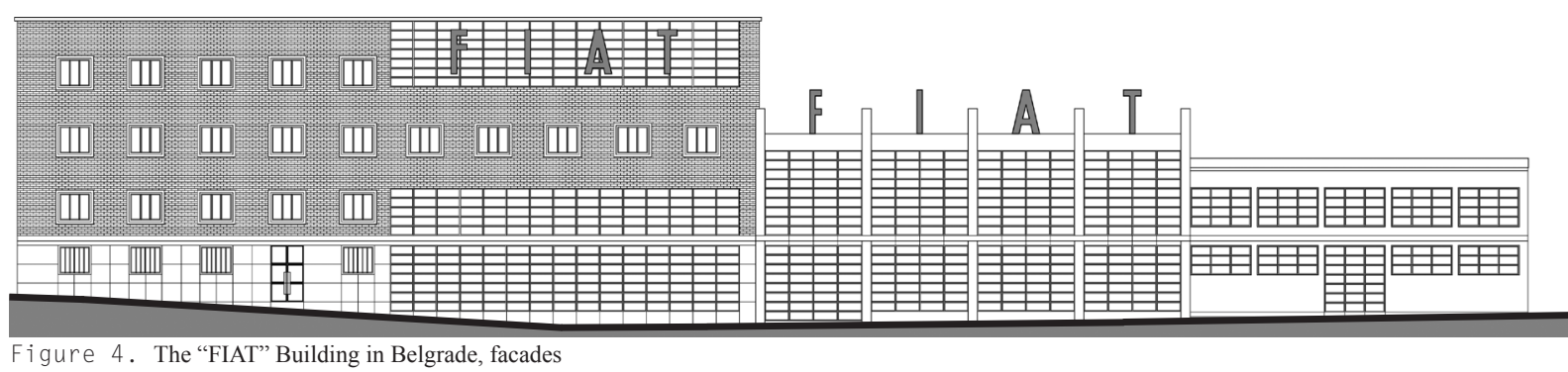


brick is encountered in the architectural expression of many authors; however, in this paper the design of Erich Mendelson for the Jewish Community Home in Tilsit (presently Sovetsk - Kaliningrad district, Russia) will be singled out, in which, besides the dynamics of the primary form, the window openings are accentuated with the stone frames.

According to Miloš R. Perović, the rounded wall surface at the corner, monolith wall carasse (fabric) executed in façade brick without accentuated joints, roof terrace with "ship" fence made of metal pipes and sections and window cuts framed with delicate stone frames are the elements of the visual art language of the Italian rationalism scattered on tens of buildings all over Italy. However, the "FIAT" building in Belgrade is profoundly Zloković's work. ${ }^{17}$

At the time when modern architecture surrendered before the growing monumentalism and totalitarianism, Zloković implemented this model of non-narrative functionality and formal restraint. The building was composed of three separate parts of diverse pragmatic requirements: the residential block with the car show room, garage and workshop. The entire composition was developed according to the requirements to satisfy diverse functional, structural and formal aspects. Through realization of this complex endeavour, Zloković's creative potential came to the limelight. Without concessions to the subjective compositional strategies, he solved the complex as the sequence of the production process which fully corresponded with the special location conditions. The garage and the workshops were organized production lines alongside the side street. The most prominent part of the building with the car show room occupied the exposed corner position, whereas the southwest, residential part made the usual main street front. The there parts were accordingly formally articulated into the expressions of their functions and structural features, but also as the individual architectural units. The effect of this balanced play of the functional units was expressed with the fullness and emptiness, the wall with transversal beams making the frame structure, and was intensified by the use of the façade material: lining of red bricks (clinker) of the building main part, the frames lined with stone in order to accentuate the structural frames and building plans, serialized windows with unified network of vertical beams on the window large openings. Even though he worked within the usual modernist discourse, Zloković departed from the pure white aesthetics of the earlier works.

No matter to which extent he traced the safe white modernistic path with the clinic (which was in finishing stages at the same time), with the "FIAT" building, Zloković, by composing the façade brick, stone frames around the windows and 
metalworkers' angular frame intuitively announced his deviation from the architecture of white and strict surfaces. Placing his modernism according to the rationalistic Terragni's line, reversing it into traditional urban block, the urban tissue of Belgrade, as if in this last work of his constructed between the two wars he demonstrated his ever present ability to question the canon and his willingness to sail out towards the new regions to be explored. With elevation of the finished grade of the traffic route Bulevar JNA (presently Bulevar oslobođenja) in 1971, the building ground-floor corpus was sheltered, for which reason the "FIAT" building is no longer perceived in its full proportion and power.

\section{SELECTED PUBLIC BUILDINGS OF ARCHITECT MILAN ZLOKOVIĆ - DISCUSSION}

The phenomenon of modernism in the architectural practice of Milan Zloković, and at the same time in the overall social-cultural and architectural context of the state of that time, has been perceived starting from the general socio-political and cultural state in Europe following the World War One, the emergence of the avant-garde art, modern architectural movements and reflexions towards the local cultural and artistic field. The Group of the architects of the modern movement (GAMM), the Serbian avant-garde personified in Ljubomir Micić's magazine Zenit, the Exhibitions of the architects and the first Salons of architecture were in the central focus of the research, and finally, through case studies of each of Zloković's four analyzed public buildings, to place them in the spatial-time framework, the context of design origination, the building realization and graphic display. The crucial modernistic discourse in the work of Milan Zloković could be marked as the period from the design of the family house in Kotež Neimar in Internacionalnih brigade street dated 1927 as far as the design for the Home of the National Health in Risan and the "FIAT" building in Belgrade dated 1940, just before the very beginning of the World War Two. These designs have been perceived and analyzed as a coherent cycle of works and designs characterized by the individual logics, mathematical elements, and sequences of form composing, complexity and structuralism of the architectural program. Out of the multitude of determinants laid down in the graphic displays of Zloković's designs and texts the principle of modern movement (modernity) has been singled out with a tendency of (non)contextuality. The analysis of the "Žiča" hotel has pointed out to the uncompromising modernity of the building. Unlike Dobrović's approach in contextualization of the "Grand" hotel at the island of Lopud by Dubrovnik 
designed in 1931 and constructed in $1936,{ }^{18}$ - where the author built the interactive contextuality of the form of fully modern hotel with the gardens and the Lopud monastery/convent so that the entire urban concept of the hotel represented the modernistic transposition of the monastery complex - the hotel representing "the ship moored for long time", it can be stated, that Zloković placed his modernity (the white ship architecture) contextually in the space of the new spa arranged park to the extent in which it affirmed the contemporary modern models and represented "the ship sailing out". ${ }^{19}$

However, in the example of Mataruška banja, which is at the distance of 13 $\mathrm{km}$ from the Žiča monastery $\left(13^{\text {th }}\right.$ century), Zloković with his architectural position and whiteness of the Mediterranean ships introduced that invisible cultural and spiritual axis which in the past was the trader's road between the medieval Serbia and Dubrovnik at the Adriatic sea by means of which the coastal archpriests participated in the construction of our sacral monuments. ${ }^{20}$

Modernism has opened the door to the contemporary Serbia and placed it on the map of European culture with the new systems of relations, progress and cultural ambience, which was fiercely interrupted by the force of the World War Two. Same as Nikola Dobrovic "in the direct contact with the builder's culture of the Dubrovnik Republic, in the designs for Dubrovnik Old Town, with the contemporary architectural means, Dobrovic attempted at establishing the interrupted continuity between the architecture of the past and the contemporary architectural practice", ${ }^{21}$ so did Zlokovic affirm his contemporariness by studying proportional lines of the Renaissance and antiques and by application of the classic proportion of the golden section and continuous division to the rhythm of the opening on his modern facades. Physical and geographical connection of Dobrović's designs in the Dubrovnik period indicates, according to his research of Marija Milinković to "the lamenting criticism of the modernistic standpoints and positions." ${ }^{22}$

The second aspect of the research comprised those modern designs by Zloković and also the buildings beyond the case studies and indicated to the innovative characteristics of the architectural buildings. The analysis of the competition entry for the building of the Maritime Museum in Split, which was prepared by Zloković in 1928, and for the Albania Palace in Belgrade dated 1938 the dynamic potential of Zloković's modernism and conceptual step forward towards the mature architectural expressions have been determined, which, unfortunately, have not been realized. 
The research of the reference frameworks of Milan Zloković's creative work as well as the individual architectural influences has demonstrated the interactions with the social context of the actual European modern and architectural paradigm, and to a lesser extent to the historical and environmental/natural context.

The basic thesis of the paper that the creative art of Milan Zlokovic between the two World Wars irrefutably affirmed the contemporary architecture of Serbia and Yugoslavia. This research has primarily confirmed the study of the contemporary architectural paradigms and theoretical, historical and modular models. The research has demonstrated also the current destruction of the modernist buildings, and particularly unprofessional and degrading interventions on Zlokovic's buildings. The transformations of the analyzed buildings developed in diverse orientations.

The ideas and concepts of the architect Milan Zloković between the two World Wars created the new research topics in the field of contemporary architectural practice and theory. The three basic topics in this paper would be apostrophized and which thread their path this paper and which have been defined in the key words terms.

The first topic is modernism and implementation of modern principles in Zloković's research discourse, which became an important link in the development of modern movement in Serbia, next to the GAMM and also the individual research recourse of the architects Nikola Dobrović and Dragiša Brašovan - the core of the modernistic creative work in our architecture. Zloković's modernism oscillated between the models taken over from the experience of the developed countries of the western and the central Europe and searching for the elements, primarily maritime architecture of stone and Le Corbusier's architecture of the "machines". In the case studies the designing aspect of composing the volumetry, rational and modular placement of the window opening and the use of the fifth façade - the roof - can be identified.

The second topic is the cultural context in Serbia, where those circumstances influencing the affirmation of the postulate of modernism can be detected as the part of the wider socio-cultural discourse in Serbia between the two World Wars. Zloković's modernism is the result of multifaceted reflexions of the modern architects, avant-garde movements and their participation in the local and international exhibitions and competitions. 
The third topic is the engagement on the theoretical, social and pedagogic plan. In this paper the fact that the key modernistic buildings were designed by Zloković in the capacity of the assistant are borne in view, and later on as the assistant professor and the professor of the Engineering Faculty, department of architecture and the Faculty of Architecture of the University in Belgrade, where he stayed until the end of his life (May 1965).

Each of the above mentioned topics opens $u$ new question and presents the possibility for further establishment of the role and value of Zloković's works, for his influence upon the architectural practice of the contemporary and future authors, for the continuity in reflexion / consideration, designing standpoints and pedagogic work with the students of architecture. 

p. 287.

The terms progressing and movement are sensed by Zoran Manević in the ship architecture set in motion, and which are explained by Ljiljana Blagojević as ,the ships on sailing out“ in the heading of the fifth chapter of her book Modernism in Serbia: the Elusive Margins of Belgrade Architecture, 1919-1941, under the title DEPARTURE (ОДЛАЗАК)

Milan Zloković, ,,Stara i nova shvatanja“, Arhitektura, Ljubljana, 1931, no. 5, pp. 143-144.

Đurđe Bošković, „Prikaz Prve jugoslovenske izložbe moderne arhitekture“, Vreme, 28.02.1931.

„The new works in beautifying the Mataruška banja/spa“, the article, Politika, 31.05.1932, p. 7.

Laza Nenadović, Banje, morska i klimatska mesta u Jugoslaviji, Beograd, Državna štamparija Kraljevine Jugoslavije, 1936.

Svetislav Ilić, Mataruška banja - turistička monografja, Kraljevo, Istorijski arhiv Kraljevo, 1969. 1941 (Cambridge, Mass.: The MIT Press / Harvard University Graduate School of Design), 2003, p. 213.

M.A. Nikolić, „Čovečanstvo nalaže da Beograd dobije modernu dečju bolnicu“, the article, Pravda, 01.05. 1933. 
"Beograd to acquire a new modern University Children Clinic“, newspaper Vreme, 11.10.1935. Ivan Zdravković, „Palata Državne štamparije i Dečija Poliklinika“, the article Pravda, 16.02. 1940

Nikola Dobrović, Savremena arhitektura 3 - Sledbenici, Beograd: Građevinska knjiga, 1963, p. 342 .

Miloš R. Perović, Srpska arhitektura XX veka: od istoricizma do drugog modernizma (Beograd: Arhitektonski fakultet Univerziteta u Beogradu), 2003, p. 108

Selim O. Han Mogamedov, „Ruski eksperiment u arhitekturi“, Istorija moderne arhitekture: Antologija tekstova, Knjiga 2/B. - Kristalizacija modernizma / Avangardni pokreti: futurizam, kubizam, ekspresionizam, de stajl, bauhaus, purizam, nova objektivnost, konstruktivizam, ed. Miloš R. Perović, Beograd: Arhitektonski fakultet Univerziteta u Beogradu, 2000, pp. 403-450.

Ljiljana Blagojević, Modernism in Serbia: the Elusive Margins of Belgrade Architecture, 1919 1941 (Cambridge, Mass.: The MIT Press / Harvard University Graduate School of Design), 2003, p. 209.

Aleksej Brkić, Znakovi u kamenu - Srpska moderna arhitektura 1930-1980 (Beograd: SAS, 1992), p. 112.

Perović, Miloš R., Srpska arhitektura XX veka: od istoricizma do drugog modernizma (Beograd: Arhitektonski fakultet Univerziteta u Beogradu), 2003, p. 109.

See in: Marija R. Milinković, Kritička praksa arhitekte Nikole Dobrovića: Dubrovački period (1934-1943), master's thesis, Univerzitet u Beogradu - Arhitektonski fakultet, 2007, p. 163.

Analyzing Dobrović's critical practice, the author places a special accent in the case study on the hotel «Grand» design dated 1935, on the island of Lopud by Dubrovnik.)

Ljiljana Blagojević, Modernism in Serbia: the Elusive Margins of Belgrade Architecture, 1919 1941 (Cambridge, Mass.: The MIT Press / Harvard University Graduate School of Design), 2003, p. 206.

The author compares the poetics of the passenger ocean-going ships with the architectonics of the Children polyclinic building by Milan Zloković, and in the spirit of Le Corbusier's texts on the ships, airplanes and cars from his book Towards the True Architecture. The conclusion of this paper's author is that by the comparison of Zloković's design of the «Žiča» hotel and Dobrović's design of the „Grand“ hotel the analogies in poetics can be perceived, however with a difference in contextual approach of these two authors.)

According to the recent researches of the historians, the master Vito Kotoranin is the presbyter of Vito Trifunov Čuča (Čučolo), the abbot of the Saint Maria church in Gurdić and procurator of the Saint Franja monastery- kotorski the builder from the 14the century who was the leading master builder of the monastery of Visoki Dečani. This monastery was the legacy of Jelena, the wife of Stefan Uroš I, the grandfather of Stefan Dečanski.

Marija R. Milinković, Kritička praksa arhitekte Nikole Dobrovića: Dubrovački period (19341943), master's thesis, Univerzitet u Beogradu - Arhitektonski fakultet, 2007, p. 163.

Ibid.,p. 163. 